\title{
Social Disorder and the Trauma of the Earth Community: Reading Hosea 4:1-3 in Light of Today's Crises ${ }^{1}$
}

\author{
KAVUSA KIVATSI JONATHAN (UNISA)
}

When elephants fight, the grass (reeds) gets hurt ${ }^{2}$

\begin{abstract}
The world currently faces terrible issues of corruption, conflicts, political instabilities, violence and injustices causing traumatic experiences for humans and nature. Likewise, Hos 4:1-3 offers a link between the corruption of the Israelite society and the wounds of the Earth community. These three verses are generally read as a ריב genre, in which Yahweh brings a lawsuit against the people of Israel. However, scholars mostly focus on the crimes and fate of humans, and ignore or silence the expression of trauma of the Earth as mourning and its non-human members as languishing. Using the framework of trauma studies, the insights of "Cosmic Covenant" from the book of Murray (1992) and the Earth Bible principles of interconnectedness and voice, this article aims to explore a unique aspect of Hosea's rhetoric of trauma establishing the relationship between people's misdeeds and the wounds of the natural world.

KEYWORDS: Trauma; Earth community; Ecological hermeneutics; cosmic covenant: creation reversal; Interconnectedness.
\end{abstract}

\section{A INTRODUCTION}

The world is confronted with critical issues of violence, conflicts, corruption, political instabilities and injustices resulting in traumatic experiences for

* Article submitted: 28/09/2016; accepted: 9/11/2016. To cite: Kivatsi Jonathan Kavusa, "Social Disorder and the Trauma of the Earth Community: Reading Hosea 4:1-3 in Light of Today's Crises," OTE 29 (3) 2016: 481-501. DOI: http:// dx.doi.org /10.17159/2312-3621/2016/v29n3a8

1 This article is based on a paper originally presented at PROPHSEM, a seminar on the prophets of the OT, at the University of South Africa on 1 September 2016. My research sojourn in Grand Rapids (USA) from September to November 2016 played a great function in the improvement of the original manuscript of this article. Thus, my thanks go to Langham Partnership (UK) and Nagel Institute (USA) for having facilitated this sojourn and access to Hekman Library at Calvin College in Grand Rapids, Michigan.

2 Joseph G. Healey, "African Proverb of the Month November: When Elephants Fight the Grass (Reeds) Gets Hurt," Afriprov.org, Nov., 2001, http://www.afriprov .org/africanproverb-of-the-month/27-2001proverbs/172-nov2001.html. 
humans and nature. Likewise, Hos 4:1-3 offers a link between the failure of the society of Israel and the wounds of the Earth community (earth, humans and non-humans creatures). Trauma studies describe a trauma situation as a state in which the subject is rendered helpless by forces that overwhelm ordinary ways of living. ${ }^{3}$ The mourning earth and its dwellers in Hos 4 seem to be in line with this definition.

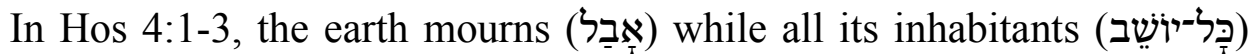
languish (אמלֵ) because of Israel's break of moral order. When used with human subjects, the root אבלל is found in funeral (Joel 1:9), judgment and lament contexts (Isa 19:1-15). In Isa 19:8-10, for instance, the root אבל מבל is paralאמל אמל (to mourn); אנה (to lament); בוש (to be ashamed/confused); דכאל (to be crushed, to be oppressed, to be in despair); and אגמי־נפש (to be distressed). אבל Nowever, ארץ (earth/land), it is paired with

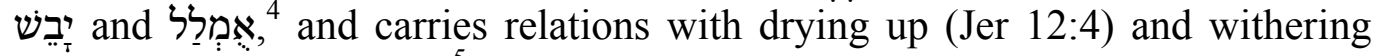
(Amos 1:2; Joel 1:10-12). ${ }^{5}$ All these verbs are typical to the signs of trauma.

It seems that the physical sign of a drought was applied to a psychological or mental condition and to the human rituals connected with it. ${ }^{6}$ There is a kind of convergence between the signs of a drought and mourning as it is

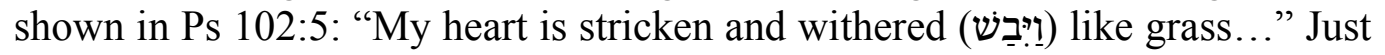
as in mourning rituals, the earth fasts or is deprived of water, the green plants wither and dust is everywhere during drought. Here is a situation of weakness intruding nature and undermining its normal way of acting and living.

Therefore, does the use of the verb אבָב and its related concepts in Hos 4:1-3 denote a state in which the earth and its members are rendered helpless by forces that overwhelm ordinary ways of living? In other words, can we describe the situation of the earth and its dwellers here in Hos 4:1-3 as trau-

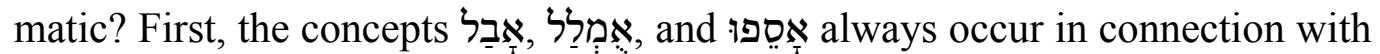
extremely negative events that severely interfere with an individual's ability to live a normal life (see Jer 12:4; 1 Sam 6:19; Isa 33:9). Second, Hos 4:1-3 embodies a gradual transition from a physical (concrete) meaning of the root אבל (to dry up) to its application to a mental state of helplessness. ${ }^{7}$ In other

3 Christopher G. Frechette, "The Old Testament as Controlled Substance: How Insights from Trauma Studies Reveal Healing Capacities in Potentially Harmful Texts," Int 69 (2015): 23.

4 See also Isa 19:8-10; 24:4-7; 33:9; Jer 14:2; Lam 2:8 and Joel 1:10-12.

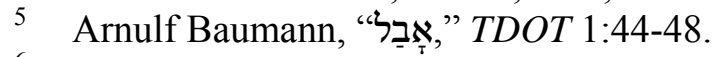

6 Katherine M. Hayes, The Earth Mourns: Prophetic Metaphor and Oral Aesthetic (Atlanta: Society of Biblical Literature, 2002), 16.

7 Godfrey R. Driver, "Confused Hebrew Roots," in Occident and Orient: Being Studies in Semitic Philosophy and Literature, Jewish History and Philosophy and Folklore in the Widest Sense in Honour of Habam Dr. M. Gaster's Eightieth Birthday, ed. Bruno Schindler and Arthur Marmorstein (London: Taylor, 1936), 75. 
words, the physical waning of the earth and its inhabitants can be termed as an expression of trauma.

This article explores whether Hosean depiction of the traumatic experience of the Earth community in response to a social dysfunction can be insightful to us today. Using the framework of trauma studies and the Earth Bible principles of interconnectedness and voice, this paper aims to explore a unique rhetoric of trauma in which Hosea establishes an inextricable relationship between human crimes and the wounds of the natural world.

\section{B APPROACHES TO HOSEA 4:1-3}

This part contains various approaches to Hos 4:1-3. It offers three categories that are representative, but not comprehensive interpretations. These are genre reading, feminist approaches and ecological reading. Both the feminist and ecological readings are covered in the Earth Bible hermeneutics. Thereafter, the section concludes with our approach combining insights of the Earth Bible hermeneutics and trauma studies.

\section{Lawsuit or Controversy (ריב) Genre Approach}

These verses are generally read as an example of the genre. The Hebrew word רִ is read as either a lawsuit or controversy. Those who favour the lawsuit reading see in Hos 4:1-3 the portrait of the prophet playing the role of an accuser in a lawsuit that YHWH initiates against the people of Israel. The use of the same word in 2 Sam 15:2 and Mic 6:1-2 supports this legal reading. A lawsuit refers to a situation where two opposing parties cannot mutually solve their dispute and decide to refer their issues to the courts. ${ }^{8}$ According to Hos 4:1-3, God brings a "covenant lawsuit" against his people and uses parts of the Decalogue (Exod 20:13-15 or Deut 5:17-19) to argue the case. ${ }^{9}$

However, those supporting the "controversy" or "quarrel" definition, argue that it is not clear that Hos 4:1-3 is precisely a covenant lawsuit. According to DeRoche, ${ }^{10}$ the term "lawsuit" is a modern concept that has no real Hebrew equivalent. He also previously said that the immediate context of Hos 4:1 does not support the legal meaning since Hos 4:1-3 lacks juridical terminology. ${ }^{11}$ In the same vein, Eidevall ${ }^{12}$ reads ריב in Hos 4:1 as portraying

8 Simon Roberts, Order and Dispute: An Introduction to Legal Anthropology (New York: Penguin Books, 1979), 17-29.

9 Hans W. Wolff, Hosea: A Commentary on the Book of the Prophet Hosea, trans. Gary Stansell (Philadelphia: Fortress, 1974), 65-74.

10 Michael DeRoche, "Yahweh's Rîb against Israel: A Reassessment of the SoCalled 'Prophetic Lawsuit' in The Preexilic Prophets," JBL 102 (1983): 564.

${ }^{11}$ Michael DeRoche, “The Reversal of Creation in Hosea," VT 31 (1981): 408.

12 Göran Eidevall, Grapes in the Desert: Metaphors, Models, and Themes in Hosea 4-14 (Stockholm: Almqvist \& Wiksell International, 1996), 53. 
the metaphorical quarrel or controversy between YHWH and the inhabitants of the land.

In both cases, the idea refers to conflict between two parties. It is obvious that the elements present in the "belong naturally to every sort of quarrel in which one party feels himself to be let down by another."13 Therefore, while both interpretations offer important insights of the text, they exclusively focus on the crimes of humans and their prosecution. In this sense, other scholars inaugurated the eco-justice interpretations of the text involving ecological and eco-feminist insights.

\section{The Earth Bible Hermeneutics}

Loya $^{14}$ reads Hos 4:1-3 through the lens of three of the six ecojustice principles of the Earth Bible Project, namely the celebrative voice of Earth and its inhabitants, the principle of interconnectedness and Nature's intrinsic worth. ${ }^{15}$ According to the Earth Bible Project, before reading a text, one has to "recognize Earth as a subject in the text with which we seek to relate empathetically rather than as a topic to be analysed rationally."16

In this sense, Loya praises Earth for her active role in the text. YHWH brings the ריב against Israel, and Earth is the agent through which this judgement is executed in Hos 4:1-3. ${ }^{17}$ Likewise, eco-feminists praise Hosea 4 for its earthly perspective. They read Hosea in comparison with the putative Canaanite fertility religion that does not devalue but gives sacral relevance to the body, sexuality and nature. ${ }^{18}$

In a different perspective, Wittenberg focuses on the relationship between justice and order as background of Hos 4:1-3. Hosea teaches that ignoring the law of Yahweh in the scramble for power and wealth damages the harmony of Israelite society and inevitably leads to disaster. ${ }^{19}$ For him, the message of Hos 4:1-3 about the relationship between human misdeeds and

13 Kirsten Nielsen, Yahweh as Prosecutor and Judge: An Investigation of the Prophetic Lawsuit (Rib-Pattern), JSOTSup 9 (Sheffield: JSOT, 1978), 25.

14 Melissa T. Loya, "Therefore the Earth Mourns: The Grievance of Earth in Hosea 4:1-3," in Exploring Ecological Hermeneutics, ed. Norman C. Habel and Peter Trudinger (Atlanta: Society of Biblical Literature, 2008), 54.

15 For the details about ecojustice principles, see Norman C. Habel, "Introducing Ecological Hermeneutics," in Exploring Ecological Hermeneutics, ed. Norman C. Habel and Peter Trudinger (Atlanta: Society of Biblical Literature, 2008), 2.

16 Habel, "Introducing," 1.

17 Loya, "Therefore the Earth Mourns," 53.

18 Alice A. Keefe, Woman's Body and the Social Body in Hosea, JSOTSup 113 (Sheffield: Sheffield Academic Press, 2001), 62.

19 Gunther Wittenberg, "Knowledge of God: The Relevance of Hosea 4:1-3 for a Theological Response to Climate Change," OTE 22 (2009): 506. 
cosmic disaster gives a surprising vision for a theological response to climate change. $^{20}$ This article lines up with this interpretation but extends it with insights from trauma studies.

\section{Ecological Framework and Trauma Theory}

This article combines insights from ecological hermeneutics and trauma studies as a theoretical framework of the analysis of Hos 4:1-3.

\section{3a Ecological Framework}

This article links up with Murray's insights on the "Cosmic Covenant" on one side, and the works of the Earth Bible project on the other. However, contrary to the Earth Bible Project, the word Earth is not capitalised throughout the article. It only viewed as a victim alongside human and non-human members of the Earth Community.

\section{(i) Cosmic covenant (Murray 1992)}

Murray insightfully revealed that the text of Hos 4:1-3, the rîb genre, is a true portrait of a broken covenant that God imposed on cosmic elements at creation. ${ }^{21}$ Murray questions why churches and theologians are anthropocentric, solely focusing on the Mosaic-Davidic covenants and ignore the all-embracing covenant: the cosmic covenant, the created order. ${ }^{22}$

This covenant or wisdom was established (כוּן) at/in creation to govern the created order as stipulated in Prov 8:22-31. According to this text, God possessed wisdom as an attribute or faculty that he used to order elements of creation. ${ }^{23}$ In this sense, at the end of his works, God looked at "the order he has made" and declared that it was very good (Gen 1:31). For Schmid, just as the Egyptian Maat, this order is maintained by the observance of justice upon the earth. $^{24}$

In this way, when this order is broken in Gen 6-8, God renewed and decreed it will be an eternal covenant (ברית־עוֹלְם) to govern relationships in the cosmos, nature and society (Gen 9:1-7). Therefore, wherever humans do justice

20 Wittenberg, "Knowledge of God," 491.

21 Robert Murray, The Cosmic Covenant: Biblical Theme of Justice, Peace and the Integrity of Creation (London: Sheed \& Ward, 1992), 31.

${ }^{22}$ Murray, The Cosmic Covenant, xix.

23 Kivatsi J. Kavusa, "The Life-Giving and Life-Threatening Potential of Water and Water-Related Phenomena in the Old Testament Wisdom Literature: An Eco-Theological Exploration." (D.Th. thesis, University of South Africa, 2015), 157.

24 Hans H. Schmid, "Creation, Righteousness, and Salvation: Creation Theology as the Broad Horizon of Biblical Theology," in Creation in the Old Testament, ed. Bernhard W. Anderson (Philadelphia: Fortress Press, 1984), 106. 
in the socio-political spheres, those actions promote the proper integration of social and cosmic orders. The contrary results in adverse consequences against the entire creation just as is the case in Hos 4:1-3.

(ii) The Earth Bible Project's Insights

This article also agrees with the work of Loya ${ }^{25}$ in the Earth Bible series, but focuses on the Earth community as a whole rather than praising Earth against human beings. In conjunction with the hermeneutics of suspicion and retrieval, this article makes use of the principle of interconnectedness and voice, two of six eco-justice principles of the Earth Bible Project to unlock ecological wisdom from Hos 4:1-3.

The element of suspicion involves that the reader suspects that biblical texts, written by humans and written for human readers, reflect primarily the interest of humans. The new ecological awareness suspects then this anthropocentric habit of the author and interpreters of the text. ${ }^{26}$

By hermeneutics of retrieval or trust, this study involves features that can enable the recovery of ecological insights from the text. In this sense, the author is guided by the Earth Bible principle of interconnectedness suggesting that "Earth is a community of interconnected living things that are mutually dependent on each other for life and survival." 27

In addition, the analysis makes use of the principle of voice entailing that "Earth is a subject capable of raising its voice in celebration and against injustice. ${ }^{28}$ In this article, this ecological awareness is combined with insights from trauma studies since the aim is to read the dysfunction in the natural word as an expression of trauma.

\section{3b Insights from Trauma Studies}

In addition to ecological insights, this article specifically analyses the text through the eyes of trauma. The presentation of Hos 4:1-3 is clearly dominated by the rhetoric of accusations (ריב-genre) embedded with expressions of lament and mourning. Nissinen ${ }^{29}$ argues that an original "summon to lamentation" text of Hos 4:1-3 was altered into a lawsuit/quarrel genre during the process of redaction. Lament and mourning are both emotional expressions of trauma.

25 Loya, "Therefore the Earth Mourns," 53-63.

26 The Earth Bible Team, "Guiding Ecojustice Principles," in Reading from the Perspective of Earth, ed. Norman C. Habel (Sheffield: Sheffield Academic, 2000), 39.

27 Habel, "Introducing," 2.

28 The Earth Bible Team, "Guiding Ecojustice," 43.

29 Martti Nissinen, Prophetie, Redaktion und Fortschreibung im Hoseabuch: Studien zum Werdegang eines Prophetenbuches im Lichte von Hos 4 und 11 (Kevelaer: Butzon \& Bercker, 1991), 134. 
In fact, trauma does not mean only suffering, but an overwhelming threat that can leave long-lasting, harmful, psychological effects or destroy social bonds or group identity. ${ }^{30}$ In this sense, a traumatic experience often resists integration into the narrative of a community/individual. Thus it is expressed through lament/mourning as it appears in the book of Lamentations. The victim is unable to make sense out of the experience within the normal sets of his or her life story. ${ }^{31}$ This means that trauma exists as a force that remains outside the normal story of life and is unable to be coherently understood or articulated. $^{32}$

In Hos 4:1-3, the victim includes the earth, humans and non-human members mourning and lamenting as result of ethical corruption and violent actions among the people of Israel upon the land. ${ }^{33}$ Commenting on the text, DeRoche speaks of Hos 4:1-3 as a "reversal of the creation"34 implying a nonintegrated event undermining the ordinary way of acting of the cosmos as planned in Gen 1:1-2:4a. This argument is emphasised by historical clues of the book of Hosea.

\section{3c Traumatic Historical Clues of Hosea 4:1-3}

The existing debates about the authorship and date of Hos 4:1-3 centre on v. 3 which is seen either as originating with Hosea or as a later addition. While Sellin $^{35}$ considers Hos 4:3a as a Hosean passage but attributes Hos 4:3b to late pre-exilic/exilic material expressing a vision of judgment, Jeremias ${ }^{36}$ claims that the whole v. 3 is a Judean addition. Others argue that the whole Hos 4:3 is an exilic reflection of the wound of the destruction of Judah and Jerusalem in 597 BCE.

However, in accordance with Hayes, ${ }^{37}$ we notice that there is an internal logic in a unified unit (Hos 4:1-3) in which the effects of the crimes introduced

30 Frechette, "Old Testament," 22.

31 Sriparna Mitra, "Traumatic Effects due to Climate Change and Global Warming," IRJIMS 2/1 (2016): 46.

32 Brad E. Kelle, "Dealing with the Trauma of Defeat: The Rhetoric of the Devastation and Rejuvenation of Nature in Ezekiel," JBL 128 (2009): 483.

33 The reoccurrence of the word ארץ (earth) in v. 1a and in v. 3 reinforces the link between the actors, those "who dwell in the land" (the people of Israel), and the respondents "all who dwell in it" which refers to the Israelites and to all other living creatures as well.

34 DeRoche, "Reversal of Creation," 403.

35 Ernst Sellin, Das Zwölfprophetenbuch (Leipzig: Diechertsche, 1929), 1:52.

36 Joachim Jeremias, Der Prophet Hosea (Göttingen: Vandenhoeck \& Ruprecht, 1983), 60 .

37 Hayes, Earth Mourns, 40. 
by כליכן (Hos 4:3) follows the indictment, introduced by (Hos). shows that v. 3 is an integral part of the theological thrust of Hos 4:1-3 and cannot be excluded from the rest. It is, thus, advised to read Hos 4:1-3 as part of Hosean material that emerged in a socio-cultural and historical situation leading up to the defeat of Israel (722 BCE) by the Assyrian empire. ${ }^{39}$

This was a period of uncertainty and upheaval in the Northern Kingdom. The mourning of the land and the languishing of all her inhabitants in Hos 4:3 as a reaction to the crimes of Israel could fit well with both political and social trauma of the nation during the period prior to the fall of Samaria and the physical effects of the invasion. ${ }^{40}$ The warning of Hos 1:4 on "bloodshed in the valley of Jezreel" by Jehu (see also 2 Kgs 9-10) would confirm this historical context.

The expression 'bloodshed strikes against bloodshed' in Hos 4:2b refers thus to internal problems portraying Israel as a decaying society prior to the defeat of 722 BCE. $^{41}$ The expression is a kind of a culmination of the list of Israel's anarchy typifying extreme randomness in Israel. In this way, the expression "all who dwell in it languish" in Hos 4:3 suggests that both human and non-human members are shocked, wounded and overwhelmed by the situation.

The experience of trauma may lie at the heart of Hosea's prophecy of the mourning, languishing and perishing of the earth community in Hos 4:1-3. The word "trauma" derives from a Greek term meaning "wound," and refers to events that pose an extreme threat and overwhelm ordinary means of coping. ${ }^{42}$ Various features of the words and actions of Hosea may be understood as indicative of the prophet's own experience of the trauma/wounds of his historical time, with its realities of corruption, injustice, crime and uncertainty culminating in the massive onslaught of the Assyrian empire in $722 \mathrm{BCE}$.

\section{TEXT AND TRANSLATION OF HOSEA 4:1-3}

\section{The Masoretic Text}

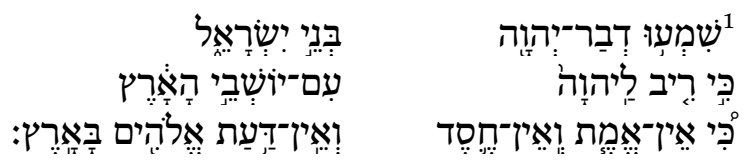

38 Wolff, Hosea, 65.

39 James M. Ward, “The Message of the Prophet Hosea," Int 23 (1969): 388.

40 R. Michael Casto, "Conversing with the Text Application of Conversational Exegesis to Hosea 4:1-3," DDSR 40 (1975): 25.

${ }^{41}$ Hayes, Earth Mourns, 49.

${ }^{42}$ Frechette, "Old Testament," 22. 


\begin{tabular}{|c|c|c|}
\hline 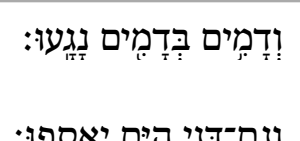 & 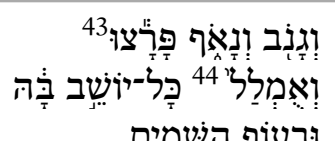 & 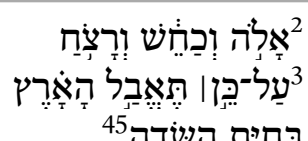 \\
\hline
\end{tabular}

\section{Translation}

This translation is based on the NRSV (1989) with some changes deriving from our reading of the textual problems of the MT.

${ }^{1}$ Hear the word of the LORD, O people of Israel;

For the LORD has a dispute with the inhabitants of the land.

There is no faithfulness or loyalty, and no knowledge of God in the land.

${ }^{2}$ Swearing, lying, and murder, and stealing and adultery break out (upon the land); bloodshed follows bloodshed.

${ }^{3}$ Therefore the land mourns, and all who live in it languish; together with the wild animals and the birds of the air, and even the fish of the sea are perishing.

\section{THE LITERARY STRUCTURE OF HOSEA 4:1-3}

This unit clearly starts a new section contrasting with the marriage metaphor of Hos 1-3 in which YHWH speaks only to an individual (Hosea), while in Tos 4:1-3, the focus shifts to all Israel. Through these verses, God brings a ריב against the people of Israel. The structure of the unit is plainly displayed: vv. 1-3 accuse Israel of certain crimes (attitudes/actions), and v. 3 points out the mourning and languishing of the earth community as result of those criminal behaviours. ${ }^{46}$

43 LXX adds here the expression $\dot{\varepsilon} \pi \grave{\imath} \tau \tilde{\eta} \varsigma \gamma \tilde{\eta} \varsigma$ (upon the land), which is בָָָר in Hebrew. It was omitted through haplography by confusing its sound with the verb . Although the difference is minor with the MT, the addition of the expression "upon the land" reinforces the central role of the land in the passage. LXX had probably been attracted by the occurrence of the word in Hos $4: 1$. Still the MT is preferred as lectio brevior assuming the LXX addition.

44 Contrary to Hayes, Earth Mourns, 38, interpreting in future all the verbs in v. 3, this article is in line with David N. Freedman, Hosea (Garden City: Doubleday, 1980), 330, and Jeremias, Hosea, 59, viewing this verse as immediate results of social disorder.

45 In accordance with Hayes, Earth Mourns, 38, the preposition בִ should not be read as stating accompaniment of the preceding expression "all who live in it" but parts of its content (humans and non-humans languish).

46 Hayes, Earth Mourns, 39. 
In this sense, Wolff ${ }^{47}$ and Jeremias ${ }^{48}$ view Hos $4: 1-3$ as a heading or thematic introduction of both the following unit (the reproach of the priests, Hos 4:4-10) and the second part of the book (Hos 4-11) furthering the failings and offenses of Hos 4:1-2. ${ }^{49}$ Still, because of its distinctive ריב genre, Hos 4:1-3 can also be apprehended as a separate unit.

\section{E ECOLOGICAL AND TRAUMA RETRIEVAL OF HOSEA 4:1-3 \\ 1 The Corruption of the Human Society}

\section{1a ריב with the Inhabitants of the Land}

The expression "the inhabitants of the land" (יוֹשְבי הָָָרָץ) in Hos 4:1 refers to humans (people of Israel) with whom YHWH has a ריב ures and crimes on earth. ${ }^{51}$ The preposition עַל־כֵּן (therefore or for this reason) in Hos 4:3 shows the link between human crimes that are pointed out by YHWH (Hos 4:1-2) and the mourning of the earth and all its members (Hos 4:3). Here is a language of trauma where the victims are overwhelmed by external forces crushing their normal way of living.

The basic mourning pattern of action-reaction is also highlighted:

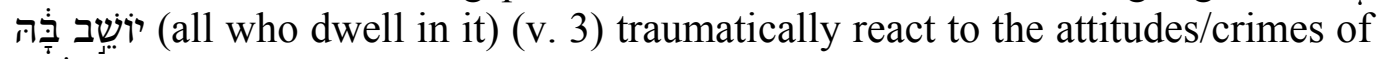

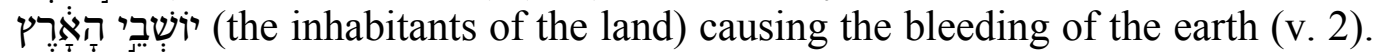
While the last Hebrew expression refers to the people of Israel, the first includes not only non-human creatures (animals, birds and fish, v. 3b) but also the Israelites themselves, whose crimes will bring them harm. ${ }^{52}$

By causing the reversal of creation through their crimes/attitudes as described in Hos 4:3, human beings should no longer expect to live normally upon the earth. In the OT, justice, politics and nature are interrelated as part of one comprehensive creation order. ${ }^{53}$ That is why after the breach of the Eden covenant, God decreed that the land will yield "thorns and thistles" (Gen 3:17-19). In other words, instead of being friendly and yielding abundant fruit, the land will be a subject of frustration and trauma for humans. This agrees with the Earth Bible principle of interconnectedness.

\footnotetext{
47 Wolff, Hosea, 65.

48 Jeremias, Hosea, 59.

49 This position was pioneered by Edwin M. Good, "The Composition of Hosea," $S E A 31$ (1966): 53, arguing that Hos 4:1-3 is a genuine Hosean oracle that was arranged by the editor to serve as an introduction to the rest of ch. 4 and perhaps the rest of the book.

50 The word rib is understood in this article as "dispute" or "quarrel" (see DeRoche, "Yahweh's Rîb," 570.

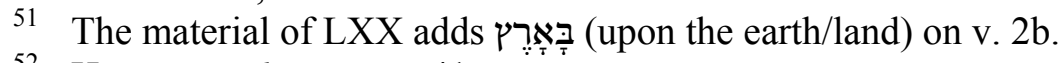

52 Hayes, Earth Mourns, 41.

53 Schmid, "Creation," 106.
} 
Therefore, the of YHWH includes the crimes of Israel and their consequences upon the earth.

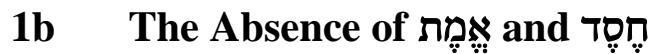

These two Hebrew words embody the ethical norms that maintain a society. The word אמֶמת is often translated by truth in connection with the word However, the meaning "to be true" entails the notion of stability, reliability, durability and faithfulness since truth is something that is constant and unchangeable. ${ }^{54}$ In this sense, all the occurrences of אֶמֶ refer to something on which one can rely or which will prove to be true in future (see Jos 2:12; Prov 11:28).

Therefore, when they are paired (אמת וחסד), the first, אמת, emphasises the permanence, certainty and lasting validity of the second חסמתד (Josh 2:14; Prov $3: 3 ; 14: 22 ; 16: 6 ; 20: 28)$. This enduring quality of חסד is deplored in Hos 6:4 accusing Ephraim that his "חסד is like a morning cloud, like the dew

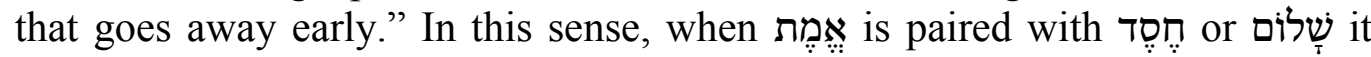
refers to a good deed/kindness on which one can rely (Gen 24:29; Jos 2:14) or a sure peace which is desired and promised in future (Esth 9:30). ${ }^{55}$

In this sense, the expression (there is no reliability or trustworthiness) is coupled with וּאין־ (and no loyalty/kindness) to give an impression of a society of randomness that is likely to cause trauma. These two Hebrew words (אמת וחסד) occur in Ps 85:11 (MT) ${ }^{56}$ as qualities of a restored land:

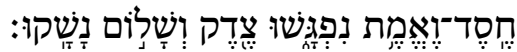

Steadfast love and faithfulness will meet; righteousness and peace will kiss each other.

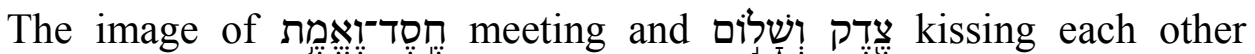
depicts an ideal society in which life is possible. The couple אמת and in Hos 4:2 can be viewed as part of social norms that function to preserve and promote life. ${ }^{57}$ Their absence means a chaotic and anarchic society as listed in Hos 4:1-2.

54 This is why the word wֶמֶ is always presented as auxiliary to in many

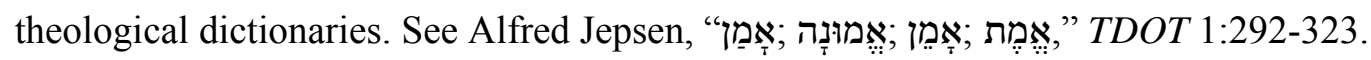
55 Jeremias, Hosea, 60.

56 In the LXX, which is the text followed by many translations, including the NRSV, it is Ps 84:10.

57 Wittenberg, "Knowledge of God," 500. 


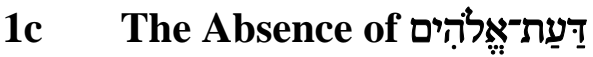

The expression דעת אלהים occurs twice in Hosea, namely Hos 4:1 and 6:6. In both cases, YHWH deplores cultic and ethical attitudes of his people. ${ }^{58}$ In this sense, the opposite of ידע (to know), the verb שכח "to forget" the knowledge of Yahweh $^{59}$ is the main reason for the indictment against the priests in Hos 4:6.

Therefore, while דעת אלהים is paralleled with דעסד in Hos 6:6, in Hos 4:1, אין-דעת אלהים (the charge is no God's knowledge) is a synonym of the lack of חסד אלחד אמת The knowledge of God which is here declared missing in Israel is thus not esoteric, but pragmatic, reflected in attitudes and actions toward others.

Wolff argues that the expression דעת אלהים in Hos 4:1 does not refer to another sphere in addition to the ethics of חסד and but that what makes them possible in Israel. ${ }^{60}$ It should be known that the ethic of אמס המת is not limited only to human sphere, but includes nature as well. This is visible in many biblical texts teaching a positive relationship with the natural world. The charge that there is no knowledge of God in the land means that Israel has forgotten that both humans and nature are part of God's order that has to be maintained by the observance of חסד אמת and.

\section{1d Swearing, Lying, Stealing and Adultery}

All these ethical crimes (lying or swearing falsely, stealing and adultery) point to a lack of reliability and compassion for the neighbour. Their presence is synonym of a failing society. The verb פָּר with with connotation of sudden incursion, the breaking of barriers, and poor growth, increases the impression of a society that has ceded its common life to random behaviours. ${ }^{61}$

The crimes of "cursing, killing, stealing, and adultery" are identical with those used in the prohibitions of the Decalogue, namely Exod 20:13-15. ${ }^{62}$ All these crimes weaken the society and pollute the earth. The book of Leviticus clearly includes adultery and corruption among acts causing the pollution of the

\footnotetext{
58 Wolff, Hosea, 182.

59 Wittenberg identifies three dimensions of God's knowledge: forgetting YHWH in favour of Baal; forgetting where the gifts of the land come from; and forgetting the Torah of YHWH. In my view, all the three dimension can be summarised by the first dimension: forgetting YHWH in favour of Baal (Wittenberg, "Knowledge of God," 5494-501).

60 Wolff, Hosea, 67.

61 Hayes, Earth Mourns, 49.

62 Scholars are divided on whether Hosea drew on the traditions of the Decalogue or the written text itself since it is not sure that the Decalogue in its current form was available by the composition of the book of Hosea. For further details, see J. Andrew Dearman, The Book of Hosea (Grand Rapids: Eerdmans, 2010), 150.
} 
earth (Lev 18:24-30). ${ }^{63}$ Hosea claims that Israel did not have the moral resources to withstand the Assyrian onslaught. ${ }^{64}$

The conclusion is that the lack of אסד wת מסד which are presumed in leads to total dysfunctions illustrated by the breaking out (פרעת אלהים cursing, lying, murder, stealing and adultery upon the earth (Hos 4:2). The verb פרץ usually refers to destructive actions such as the breaking into a house, the bursting out of water and breach of defence works. ${ }^{65}$ Hosea 4:2 gives a picture of a society in total disorder with all community relationships disrupted.

\section{1e Bloodshed Strikes against Bloodshed}

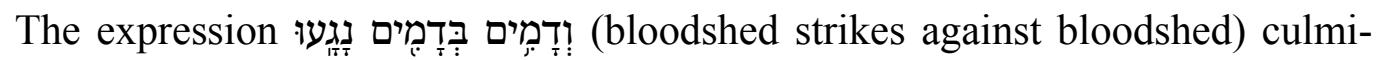
nates the social disorder in Israel. The various senses of the verb נָגֵע (to touch, reach, strike) entails

that not only does blood "touch" or "reach" bloodshed, implying that it is everywhere, but bloodshed "strikes" bloodshed, illustrating the way violence breeds violence and heightening the sense of Israel as a war zone. ${ }^{66}$

The image of דמים not only suggests the lack of respect to the neighbour, but also precludes another theme in the tradition of Israel: the pollution of the earth or the defilement of the land as stipulated in the Holiness Code in Leviticus. ${ }^{67}$ The pollution of the earth is expressed by the roots טמא (to be unclean, Lev 18:25), and חנף (to be polluted, Isa 24:5; Jer 3:1) as well as the expression ותקא הארץ (the earth vomits). ${ }^{68}$

Likewise, human bloodshed is regarded as a fundamental act of defilement of the earth in the book of Num 35:33a declaring:

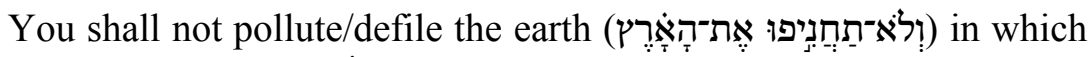

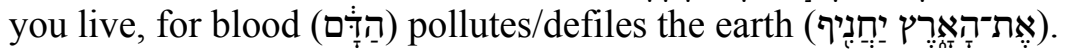

The sanction of bloodshed crime is given in the story of Cain and Abel. Not only Cain (humans) was cursed from the ground upon which Abel was

63 See also Deut 24:1-4.

64 Wittenberg, "Knowledge of God," 503.

${ }^{65}$ Francis, Brown, Samuel R. Driver and Charles Briggs, eds. The Brown-DriverBriggs Hebrew and English Lexicon (London: Oxford University Press, 1968), 829.

66 Hayes, Earth Mourns, 49.

67 Tikva S. Frymer-Kensky, "Pollution, Purification, and Purgation in Biblical Israel," in The Word of the Lord Shall Go Forth: Essays in Honour of David Noel Freedman in Celebration of His Sixteenth Birthday, ed. Carol L. Meyers and Michael P. O’Connor (Winona Lake, IN: Eisenbrauns, 1982), 406.

68 Esias E. Meyer, "People and Land in the Holiness Code: Who is YHWH's Favourite?" OTE 28 (2015): 338-39. 
killed, but also the earth became "infertile" (Gen 4:11-12). It is as if the blood of Abel weakened the fertility potential of the earth. That is why, after the flood, God prohibits the shedding of human blood (Gen 9:5-6). Furthermore, letting the dead corpse hang on the ground pollutes the land according to Num 35:31-34.

The summation of bloodshed and other crimes (lying, stealing and adultery) cause the land to mourn; a mourning termed in the same Hebrew word that means to become dry or wither (אבל). ${ }^{69}$ The LXX's gloss on Hos 4:2 clearly establishes a link between the crimes of Israel, blood, and the trauma of the earth:

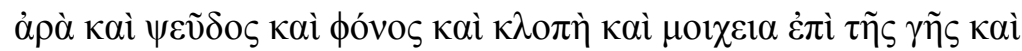

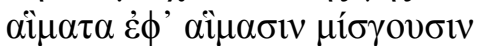

Curse and falsehood and murder and theft and adultery have been poured upon the earth, and blood deeds mix with bloody deeds.

The following section is devoted to read the mourning of the earth as an expression of trauma.

\section{The Traumatic Response of the Earth}

\section{2a Present/Future Trauma of the Earth Community!}

Scholarly interpretations of Hos 4:1-3 diverge about whether v. 3 describes a present distress/trauma in the natural order because of Israel's ethical failure ${ }^{70}$ or whether the distress/trauma is God's future judgment over Israel. ${ }^{71}$ Literary evidences in other earth mourning texts would support the second option.

However, contrary to its pairs in which the mourning of the earth is presented as God's judgment, in Hos 4 the situation is quite different. The use of the preposition על־כן rather than לכן Hos 4:3 is insightful. Although both can be translated by "therefore," לכן tends to precede a divine declaration of a judgment, whereas על־כן generally introduces the necessary result of an action, usu-

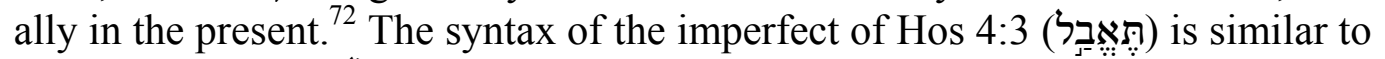

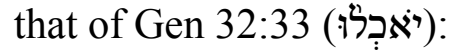

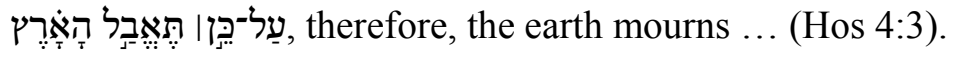

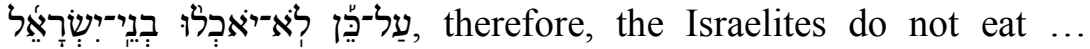
(Gen 32:33).

69 Frymer-Kensky, "Pollution," 408.

70 Ward, "Message," 389.

71 Wolff, Hosea, 65.

72 Hayes, Earth Mourns, 45. 
In this sense, Hos 4:1-3 differs from Amos 1:2 in which the drought of the land is caused by the roar of YHWH. What stands out in Hos 4 is the implication that ארץ is inseparably linked with the quality of Israel's life upon the land. ${ }^{73}$ That is why, in addition to the Hebrew text that has the word ארץ only in vv. 1 and 3, the LXX also adds the in v. 2 of Hos 4:1-3, a variant underlining the link between human actions and the fate of the earth. The land that was given by God to Israel for life was never intended to sustain this mockery over which the earth mourns. The charge of YHWH against Israel seems to include not only their crimes, but also the damage/trauma their attitudes and acts have brought upon the earth.

\section{2b The Earth Mourns}

Traumatic events are viewed as dangerous to self or others, and overwhelm the victim's ability to respond adequately. ${ }^{74}$ In this sense, the earth mourns as response to human crimes upon it. The earth's mourning is conveyed by the אבל Means "to mourn" when used with human subjects (Joel 1:9; Jer 14:2), while the situation is complex when it is paired with In a number of prophetic texts where אבל occurs, it bears association with "drying up"75 and is coupled with other related verbs. In Amos 1:2 and Joel 1:10, for instance, יבש (to wither) to suggest drought.

It seems that drought is the physical background of the psychological meaning of אבל as "to mourn" when paired with human subjects. ${ }^{76}$ The drying up of the earth is a kind of traumatic earthly way of reacting to an overwhelming situation. $\mathrm{O}^{\prime} \mathrm{Connor}^{77}$ argues that victims of a traumatic disaster "cannot absorb, understand, or grasp violence as it is happening because traumatic violence overwhelms the senses." Thus, the earth dries up or mourns.

The drought makes the earth to act in an abnormal way: the mourning of the earth is synonymous of "stripping" or "being naked," which has the connotations of a shameful state of the earth (Hos 2:12-14). Trauma victims experience the sense of "shame," being out of control, devastated, defeated and helplessness. ${ }^{78}$ According to Hos 2:12-14, the external signs of the earth's pollution is to wither, a state of joylessness or mourning: the land becomes like a desert, naked and unable to support life.

73 James A. Wharton, “Hosea 4:1-3," Int 32/1 (1978): 79.

74 Glenn R. Schiraldi, Post-Traumatic Stress Disorder: A Guide to Healing, Recovery, and Growth, 2nd ed. (London: McGraw Hill, 2009), 3.

${ }_{75}$ Amos 1:2; Jer 4:23-28; 12:1-13; 23:9-12; Isa 24:1-20; 33:7-9 and Joel 1:5-20; Hos 4:1-3.

76 Delbert R. Hillers, “The Roads to Zion Mourn,” Per 12/1-2 (1971): 124.

77 Kathleen M. O’Connor, Jeremiah: Pain and Promise (Minneapolis: Fortress Press, 2011), 13.

78 Schiraldi, Post-Traumatic, 394. 
According to Smith-Christopher, a disaster is traumatic "only when events exceed the ability of the group to cope, to redefine and reconstruct their world." ${ }^{, 79}$ The earth's mourning situation in Hos 4:3 is actually the visible sign of the inability of the earth to function in a normal way due to awful human actions and attitudes upon it.

The earth's mourning in Hos 4:3 can also be termed as the loss of the normal way of speaking. Trauma studies argue that traumatic events are not only absorbed, but also destroy the victim's language. Chaney says that trauma is "wound in a language," "the unspeakable" that language sometimes fails to express. ${ }^{80}$ Most victims of war and rape in the East of the Democratic Republic of the Congo were mourning, lamenting, crying and accounting clichés, such as "it was beyond words." 81

The earth mourning (אבל) in Hos 4:3 is a traumatic way of voicing the "unspeakable" since mourning, screaming or groaning is typical of a pre-language state disconnected from traditional ways of speaking. ${ }^{82}$ The physical meaning of אבל as "to dry up" expresses the earth's inability to cope with an overwhelming external force. The mourning earth is in accordance with the Earth Bible principle of voice.

\section{2c All its Inhabitants Languish (צִמְלִל)}

Here in Hos 4:3, the verb אמִלְל (languish) is paired with אבל in order to account a vast sorrow affecting all elements of creation, including humans, animals, birds and fish. In other words, the verse raises the image of a severe drought, through which אֶרֶ becomes dry, and humans, animals, birds and fish weaken

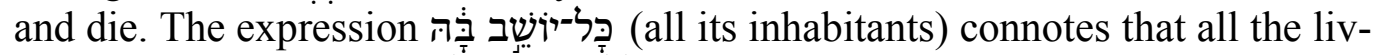

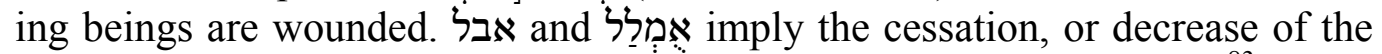
normal life, entailing a breaking off of natural productivity and growth. ${ }^{83}$

The physical meaning of the root means "to waste away or to be weak" in the sense of losing fertility and life-bearing potential (Isa 16:8; 1 Sam 2:5; Jer 15:9). In the context of Hos 4, it may even entail a declining of fauna population. In this sense, the verb אמל is often paired with אבל in mourn-

79 Daniel A. Smith-Christopher, A Biblical Theology of Exile (Minneapolis: Fortress Press, 2002), 79.

80 Michael A. Chaney, "Trauma is a Wound in Language: Meta Moments that Crash Narrative," michaelalexanderchaney: literary fictions, flashes, fiascos, 5 Oct. 2013, https://michaelalexanderchaney.com/2013/10/05/trauma-is-a-wound-in-languagemeta-moments-that-crash-narrative/.

81 Kambale Sikiryamuva (38 years old), interviewed in Butembo on 23 may 2016.

82 Elaine Scarry, The Body in Pain: The Making and Unmaking of the World (New York: Oxford University Press, 1985), 6.

83 Hayes, Earth Mourn, 45. 
ing and lament contexts in which the weakening or declining sense is metaphorically widened to include a psychological meaning. ${ }^{84}$ To be weak or waste away is typical of a traumatised person.

Therefore, there is insightful trauma parallelism between the "dryness (יבשש) of the Nile River" in Isa 19:5-10 and the languishing or weakening of

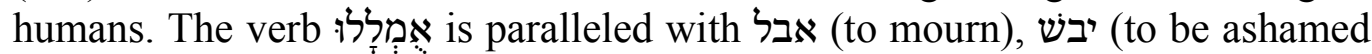

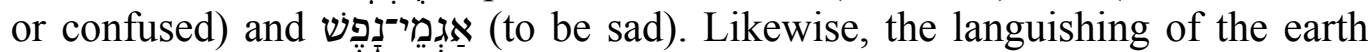
community in Hos 4:2 implies a kind of depression in the natural world. The Cambridge Dictionary defines the verb to languish as "to exist in an unpleasant or unwanted, and overwhelming situation often for a long time." 85

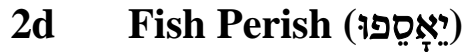

The verb יאָָספָו: is used in the last part of v. 3 regarding the trauma of fish: they are perishing. The verb יאָזָי means "to be gathered or harvested." The verb occurs in pual (an intensive passive form) to suggest not only the severity of the action, but that the victims are overwhelmed by an external force. The pual יאָָסָפו brings out agricultural aspects of a drought.

While crops are normally harvested at the end of a season, in Hosea the verb יאָָספוּ refers to an abnormal harvest which is caused by drought (אבל).

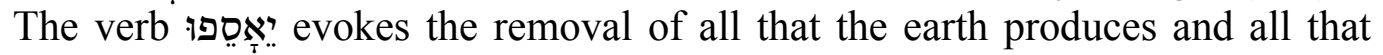
covers and beautifies the earth. The earth experiences failure, bareness and shame because of human crimes, a result of the lack of knowledge of God that sustains the maintenance of אֶֶֶ and

Through drought, the land returns to its pre-creation state of waste and void, incapable of sustaining any form of life.

\section{2e Trauma as the Reversal of Creation}

The words associated with the mourning of the earth, the languishing of all its inhabitants and the perishing of fish in Hos 4:3 convey not only a great drought, but the faltering of all creation. ${ }^{87}$ Humans and non-human members suggest the totality of the living beings. Hosea 4:3 recalls all the living beings of the two creation accounts (Gen 1-2). Although, the Priestly and Yahwist cre-

84 Hayes, Earth Mourns, 43.

85 Cambridge Dictionary, "Languish," http://dictionary.cambridge.org/us/dictionary /english/languish.

86 Hayes, Earth Mourns, 44.

87 Jeremias, Hosea, 62. 
ation stories postdate Hos 4:3, the three categories of animals (land animals, birds and fish) recall the traditional phraseology used in creation texts. ${ }^{88}$

Just as in Gen 6 where creation is undone by the flood, Hos 4:3 and later Zeph 1:2-3 portray de-creation by drought. In fact, both flood (wet chaos) ${ }^{89}$ and drought (dry chaos) ${ }^{90}$ portray the return to a pre-creation state in the HB. ${ }^{91}$ The pairing of אֶרץ with the verb שֶחז (to be ruined, spoiled and corrupted) in Gen 6:11 recalls the defilement theme of Hos 4:2 in which spoiled by violence, especially bloodshed.

However, while in Gen 6 God unleashes the flood to destroy מֶר human acts and attitudes de-create the earth in Hos 4:3: they cause the drought of the earth as well as the languishing of all its inhabitants. Human actions/attitudes are so disastrous that the earth community cannot integrate them in its real existence, and thus relies on mourning (drying up) and languishing (weakening) that can be termed as the trauma of the earth community.

The verb אָבל אָל having a dual meaning of "to mourn" and "to dry up," and אִמְלֵל that connotes "declining" and "cessation of fertility" suggest that all humans, fauna and fish are affected by drought. In other words, the dry chaos removes all forms of life (humans, plants, animals, birds, fish), and becomes again a formless void. ${ }^{92}$ The land and all its mourning inhabitants are the "formal reversal" of the image of cosmic harmony previously stated in Hos $2: 18 .^{93}$

That is why DeRoche speaks of the undoing or reversal of creation order in Hos 4:3. ${ }^{94}$ The words ecocide, geocide and biocide are now used to mean adverse alterations, often irreparable, to the environment. ${ }^{95}$ It is in this sense

88 See Gen 2:19 and Gen 1:26. Similar creation phraseology is visible in both the Atrahasis and Gilgamesh Epics: "the Beast of the field, the fowl of the sky." These animals are named in the flood narratives as "birds, beasts and crawling things of the earth" in both $\mathrm{P}$ (Gen 6:20) and $\mathrm{J}$ (Gen 7:23) accounts.

89 It is like the flood was a divine purgation of a polluted earth (Frymer-Kensky, "Pollution," 409).

90 Many occurrences on the word מִדְבֵּר (desert) or "dry land" related to a region which is hostile to life, uncertain and dangerous, the domain of outlaws and wild animals (see Jer 2:6).

91 Nicholas J. Tromp, Primitive Conceptions of Death and the Nether World in the Old Testament (Rome: Pontifical Biblical Institute, 1969), 132.

92 Hayes, Earth Mourns, 59.

93 Murray, Cosmic Covenant, 50.

94 DeRoche, "Reversal of Creation," 401

95 William A. Schabas, Genocide in International Law: The Crime of Crimes, 2nd ed. (New York: Cambridge University, 2009), 235. 


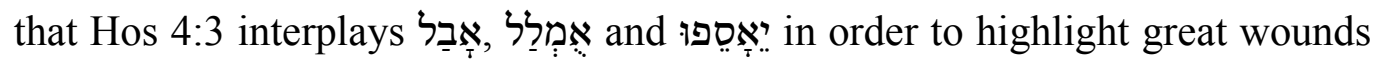
experienced in the natural order.

\section{F THE EARTH MOURNING IN OTHER PROPHETIC TEXTS}

A number of prophetic texts ${ }^{96}$ establish a link between the mourning of the earth and the crimes of human beings. Jeremiah 4:23-28, for instance, shows the image of a desolate land deserted by humans and birds. The mourning picture is even more vivid in Jer 14:2-6: "Judah mourns and her gates languish; they lie in gloom on the ground, and the cry of Jerusalem goes up." Thereafter follows a description of wounds of the farmers due to drought, and its drastic effects on the beasts of the field.

In these texts, however, the trauma of the earth is caused by the speech of YHWH. God plagues the earth because of human crimes. In contrast, Hos 4:1-3 creates an impression of a land directly reacting to the acts done upon it. That is why the situation in Hos 4:3 can be termed as a traumatic reaction of the earth community. In Hos 4:1-3, YHWH has a ריב with Israel because of their crimes and the wounds their acts have caused upon the earth.

\section{G CONCLUSION}

This article tries to read the de-creation of the earth community in Hos 4:1-3 as the expression of trauma in the natural world. All the signs of trauma are present in the text: traumatic events are external events, they overwhelm the victims and leave them in a traumatic situation of helplessness. Finally, Hos 4 can be insightful to modern people that humans are interconnected with the earth community. Their actions upon the earth cause trauma of the earth and non-human members, but will affect them as well.

\section{BIBLIOGRAPHY}

Botterweck, G. Johannes, Helmer Ringgren and Heinz-Josef Fabry, ed. Theological Dictionary of the Old Testament (TDOT). 15 vols. Grand Rapids: Eerdmans, 1974.

Brown, Francis, Driver, Samuel and Briggs, Charles eds. The Brown-Driver-Briggs Hebrew and English Lexicon. London: Oxford University Press, 1968.

Cambridge Dictionary. "Languish," http://dictionary.cambridge.org/us/dictionary/english languish.

Casto, R. Michael. "Conversing with the Text Application of Conversational Exegesis to Hosea 4:1-3." Duke Divinity School Review 40/1 (1975): 18-33.

Chaney, Michael A. "Trauma is a Wound in Language: Meta Moments that Crash Narrative," michaelalexanderchaney: literary fictions, flashes, fiascos, 5 Oct. 2013,

96 These are some of them: Amos 1:2, Jer 4:23-28; 12:1-4, 7-14; 14:1-6; 23:9-12; Isa 24:1-20; 33:7-9 and Joel 1:1-20 etc. For a better analysis of the mourning texts, see Hillers, "Roads," 121-134; and Hayes, Earth Mourns. 
500 Jonathan, "Social Disorder and the Trauma," OTE 29/3 (2016): 481-501

https://michaelalexanderchaney.com/2013/10/05/trauma-is-a-wound-in-languagemeta-moments-that-crash-narrative/.

Dearman, J Andrew. The Book of Hosea. Grand Rapids: Eerdmans, 2010.

DeRoche, Michael. "The Reversal of Creation in Hosea." Vetus Testamentum 31 (1981): 401-409.

. "Yahweh's Rîb Against Israel: A Reassessment Of The So-Called 'Prophetic Lawsuit' In The Preexilic Prophets.” Journal of Biblical Literature 102/4 (1983): 563-574.

Driver, Godfrey R. "Confused Hebrew Roots.” Pages 75-77 in Occident and Orient: Being Studies in Semitic Philosophy and Literature, Jewish History and Philosophy and Folklore in the Widest Sense in Honour of Habam Dr. M. Gaster's Eightieth Birthday. Edited by Bruno Schindler and Arthur Marmorstein. London: Taylor, 1936.

Earth Bible Team, The. "Guiding Ecojustice Principles." Pages 38-53 in Reading From the Perspective of Earth. Edited by Norman C. Habel. Sheffield: Sheffield Academic Press, 2000.

Eidevall, Göran. Grapes in the Desert: Metaphors, Models, and Themes in Hosea 4-14. Stockholm: Almqvist \& Wiksell International, 1996.

Frechette, Christopher G. "The Old Testament as Controlled Substance: How Insights from Trauma Studies Reveal Healing Capacities in Potentially Harmful Texts." Interpretation 69/1 (2015): 20-34.

Freedman, David N. Hosea. Garden City: Doubleday, 1980.

Frymer-Kensky, Tikva S. "Pollution, Purification, and Purgation in Biblical Israel." Pages 399-414 in The Word of the Lord Shall Go Forth: Essays in Honour of David Noel Freedman in Celebration of His Sixteenth Birthday. Edited by Carol L. Meyers and Michael P. O'Connor. Winona Lake, IN: Eisenbrauns, 1982.

Good, Edwin M. “The Composition of Hosea.” Svensk Exegetisk Arsbok 31 (1966): 21 63.

Habel, Norman C. "Introducing Ecological Hermeneutics." Pages 1-8 in Exploring Ecological Hermeneutics. Edited by Norman C. Habel and Peter Trudinger. Atlanta: Society of Biblical Literature, 2008.

Hayes, Katherine M. The Earth Mourns: Prophetic Metaphor and Oral Aesthetic. Atlanta: Society of Biblical Literature, 2002.

Healey, Joseph G. "African Proverb of the Month November: When Elephants Fight the Grass (Reeds) Gets Hurt.” Afriprov.org: African Proverbs, Sayings and Stories, Nov. 2001, http://www.afriprov.org/african-proverb-of-the-month/27-2001proverbs 1172-nov2001.html.

Hillers, Delbert R. “The Roads to Zion Mourn.” Perspectives 12/1-2 (1971): 121-134. Jeremias, Joachim. Der Prophet Hosea. Göttingen: Vandenhoeck \& Ruprecht, 1983.

Kavusa, Kivatsi J. "The Life-Giving and Life-Threatening Potential of Water and WaterRelated Phenomena in the Old Testament Wisdom Literature: An Eco-Theological Exploration.” D.Th. thesis, University of South Africa, 2015.

Keefe, Alice A. Woman's Body and the Social Body in Hosea. Journal for the Study of the Old Testament Supplement Series 113. Sheffield: Sheffield Academic Press, 2001 . 
Jonathan, "Social Disorder and the Trauma," OTE 29/3 (2016): 481-501

Kelle, Brad E. "Dealing with the Trauma of Defeat: The Rhetoric of the Devastation and Rejuvenation of Nature in Ezekiel." Journal of Biblical Literature 128/3 (2009): 469-490.

Loya, Melissa T. "Therefore the Earth Mourns: The Grievance of Earth in Hosea 4:1-3." Pages 53-63 in Exploring Ecological Hermeneutics. Edited by Norman C. Habel and Peter Trudinger. Atlanta: Society of Biblical Literature, 2008.

Meyer, Esias E. "People and Land in the Holiness Code: Who is YHwH's Favourite?" Old Testament Essays 28/2 (2015): 333-450.

Mitra, Sriparna. "Traumatic Effects due to Climate Change and Global Warming." International Research Journal of Interdisciplinary and Multidisciplinary Studies 2/1 (2016): 46-62.

Murray, Robert. The Cosmic Covenant: Biblical Theme of Justice, Peace and the Integrity of Creation. London: Sheed \& Ward,1992.

Nielsen, Kirsten. Yahweh as Prosecutor and Judge: An Investigation of the Prophetic Lawsuit (Rib-Pattern). Journal for the Study of the Old Testament Supplement Series 9. Sheffield: JSOT, 1978.

Nissinen, Martti. Prophetie, Redaktion und Fortschreibung im Hoseabuch: Studien zum Werdegang eines Prophetenbuches im Lichte von Hos 4 und 11. Kevelaer: Butzon \& Bercker, 1991.

O'Connor, Kathleen M. Jeremiah: Pain and Promise. Minneapolis: Fortress Press, 2011.

Roberts, Simon. Order and Dispute: An Introduction to Legal Anthropology. New York: Penguin Books, 1979.

Scarry, Elaine. The Body in Pain: The Making and Unmaking of the World. New York: Oxford University Press, 1985.

Schabas, William A. Genocide in International Law: The Crime of Crimes. 2nd edition. New York: Cambridge University Press, 2009.

Schiraldi, Glenn R. Post-Traumatic Stress Disorder: A Guide to Healing, Recovery, and Growth. 2nd ed. London: McGraw Hill, 2009.

Schmid, Hans H. "Creation, Righteousness, and Salvation: Creation Theology as the Broad Horizon of Biblical Theology." Pages 102-117 in Creation in the Old Testament. Edited by Bernhard W. Philadelphia: Fortress Press, 1984.

Sellin, Ernst. Das Zwölfprophetenbuch. Erste Halfte: Hosea-Micha. Vol. 12. Leipzig: Diechertsche, 1929.

Smith-Christopher, Daniel A. A Biblical Theology of Exile. Minneapolis: Fortress Press, 2002.

Tromp, Nicholas J. Primitive Conceptions of Death and the Nether World in the Old Testament. Rome: Pontifical Biblical Institute, 1969.

Ward, James M. “The Message of the Prophet Hosea.” Interpretation 23 (1969): 387-407. Wharton, James A. "Hosea 4:1-3." Interpretation 32/1 (1978): 78-83.

Wittenberg, Gunther. "Knowledge of God: The Relevance of Hosea 4:1-3 for a Theological Response to Climate Change." Old Testament Essays 22/2 (2009): 488-509.

Wolff, Hans W. Hosea: A Commentary on the Book of the Prophet Hosea. Translated by Gary Stansell. Philadelphia: Fortress, 1974.

Dr Kavusa Kivatsi Jonathan, is a lecturer in Biblical Studies at the Université Libre des Pays des Grands Lacs, Goma, Democratic Republic of the Congo. Email: jokakiv@yahoo.fr. 